\title{
Impact of climate change on water balance of forest sites in Rhineland-Palatinate, Germany
}

\author{
G. V. Grigoryan ${ }^{1}$, M. C. Casper ${ }^{1}$, J. Gauer ${ }^{2}$, A. C. Vasconcelos $^{3}$, and P. P. Reiter ${ }^{1}$ \\ ${ }^{1}$ University of Trier, Department of Physical Geography, Trier, Germany \\ ${ }^{2}$ Forest agency of Rhineland-Palatinate, Koblenz, Germany \\ ${ }^{3}$ Albert-Ludwigs-University of Freiburg, Institute for Landscape Management, Freiburg, Germany
}

Received: 19 January 2010 - Revised: 1 June 2010 - Accepted: 9 June 2010 - Published: 25 August 2010

\begin{abstract}
It is expected that the biomass productivity of forest stands will be influenced by global climate change. In order to adapt forest management to this fact a model based approach was developed in cooperation with forestry experts. The concept aims at detecting the link between climate, terrain and soil parameters with the biomass productivity of some tree species. This article gives an insight into the first two steps of this approach. At first the WaSiMETH 8.2 model was parameterised to simulate various forest sites. Furthermore, different drought stress indices were applied to the simulated water balance time series. The impact of variations of climate, topography and soil characteristics on water balance was plausibly simulated. All drought stress indices detected years which were dominated by dry conditions. However, the indices related to soil water content were more selective than those related to evapotranspiration. Drought stress indices for one future climate projection have shown an increasing frequency of drought stress during vegetation period. Thus, the first two steps are capable components to detect the link between water balance with climate, terrain and soil parameters.
\end{abstract}

\section{Introduction}

It is expected that global climate change will influence the water balance in Rhineland-Palatinate (SW-Germany) due to modified temperature and precipitation distribution. Consequently, the change of water balance affects economic and natural sectors. For example, forestry is endangered because on the one hand the biomass productivity of tree stands is closely related to the soil water regime (Gauer, 2009) and

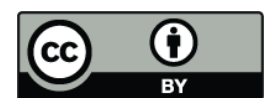

Correspondence to: G. V. Grigoryan (grigorya@uni-trier.de) on the other hand drought stress reduces the tree's defences against insects and other pests (Engesser et al., 2008; Petercord, 2008).

Hence, for regional forest management planners it is necessary to know how the biomass productivity of different tree species will be affected by climate change. Therefore, it is required to determine the existing link between climate parameters and biomass productivity. Until now the regional forest agency in Rhineland-Palatinate uses precipitation as primary climate parameter to detect the water balance degree of a site, which is related to biomass productivity. It is assumed that the existing relationship between climate parameters and water balance should be revised in order to assess the impact of climate change. Because appropriate measured data is not available, a model based approach must be developed in cooperation with forestry specialists, which allows to integrate the impact of climate change on water balance degree and on biomass productivity in forest management planning. Similar concepts are applied for forest sites in other German states like Bavaria (Falk et al., 2008; Schultze et al., 2005) and Saxony (Schwärzel et al., 2008), but cannot be simply adapted for Rhineland-Palatinate, because of a different, well founded philosophy in the determination of water regime in the existing site maps (AStOK, 2003). The aim of this study is to develop plausible methodical components for a concept which finally allows investigating the correlation between climate, terrain and soil parameters with biomass productivity.

\section{Methodology}

\subsection{Concept}

First, a hydrological model was parameterized to simulate various forest sites while changing climate input (measured and projected), topology and available water capacity

Published by Copernicus Publications on behalf of the European Geosciences Union. 
(AWC). In the next step, different water use and drought stress indices were defined and finally applied to the simulated water balance time series in order to indicate time periods in which tree species suffer drought stress. Sites with lower AWC and south exposition were expected to show more intense and more frequent periods of drought stress, but the intensity of the non-linear system reaction had to be determined.

\subsection{Hydrological model}

In this study the WaSiM-ETH 8.2 model was used for hydrological simulations. Hydrological processes in the model are based on physical and conceptual descriptions (Schulla and Jasper, 2007). The specific advantage of WaSiM-ETH 8.2 for the present study was the possibility of in-detail simulation of soil water transport in the unsaturated zone after van Genuchten (1980), evapotranspiration using the PenmanMonteith equation (Monteith and Unsworth, 1990) and the topography dependent adjustment of radiation and temperature after Oke (1987).

\subsection{Site description}

Simulations were restricted to a single model cell. A 100 year old beech forest stand represents the upper boundary condition. Furthermore, soil texture was chosen to be silty loam, for representing the most common soil type in Rhineland-Palatinate (SW-Germany). Only one-dimensional vertical soil water fluxes in the unsaturated zone were considered while assuming that the input of lateral soil water by interflow equals its loss. The lower boundary condition was set to a depth of $5 \mathrm{~m}$, at which groundwater exfiltrates.

In order to simulate different water balance conditions, the available water capacity $(50 \mathrm{~mm}, 100 \mathrm{~mm}, 150 \mathrm{~mm}$, $200 \mathrm{~mm})$, the exposition (north and south) and the slope $\left(0^{\circ}\right.$ and $20^{\circ}$ ) were changed, so that a total of twelve different variations were simulated for each site.

\subsection{Parameterisation and plausibility}

Because the simulations were not applied to a catchment but to a single model cell, only the model parts of evapotranspiration, snow (accumulation and melt), interception, unsaturated zone soil water transport and groundwater flow were activated.

The parameterisation of the 100 year old beech forest was based on the standard deciduous forest of WaSiM-ETH 8.2 but changed according to experience. Adapted parameters were leaf area index, maximum root depth, aerodynamic roughness length, resistances concerning evapotranspiration and vegetation cover factor.

Soil specific van Genuchten (1980) parameters for three different horizons with a total of 67 layers were chosen according to Teepe et al. (2003). Values of the saturated conductivity were based on AG Boden (2005) but modified ac- cording to laboratory analysis (Sauer, 2009). Different conditions for available water capacity were determined by reducing the saturated water content.

In order to control the simulation results, the model behaviour was analysed by comparison of expected and simulated soil water tension. WaSiM-ETH 8.2 should be able to reproduce dehydration tendencies in late spring and during summer months as well as recharge of the reservoir in late autumn and winter. The main goal was not to reproduce values from measurement stations but to be able to resemble natural variations in a plausible way. In addition water balances were determined and compared to data of measurement stations from Ellenberg (1986) which were similar to the simulated sites.

\subsection{Climate time series}

Time series of five different variables (precipitation, temperature, humidity, wind speed and global radiation) for a daily time step were required to run simulations with WaSiMETH 8.2. The simulations were carried out for two time periods at the site "Deuselbach". First the measured period from 1951 to 2003 was simulated. The required daily timestep data were derived from the meteorological station of the DWD ("Deutscher Wetterdienst") at "Deuselbach". In a second step the same variations were simulated for a future scenario from 2061 to 2100 . To this end, the climate projection of the WETTREG realisation A1B normal of "Deuselbach" was used. WETTREG is a statistical downscaling method which is based on classification of weather conditions and on data from meteorological stations (Spekat et al., 2006).

\subsection{Drought stress indices}

The drought stress indices were used to quantify the intensity, duration and frequency of dehydration periods. These indices were developed according to literature references (Asche, 2001; Falk et al., 2008; Laatsch, 1969; Schultze et al., 2005; Wessolek, 1989) as well as expertise from the regional forest agency. The three indices described hereafter were calculated for each time step.

\subsubsection{Soil water tension (SWT)}

This index describes the soil water tension in the root zone as shown in Eq. (1). For each day a mean soil water tension $\mathrm{SWT}_{\text {rootzone }}$ was calculated. The individual soil water tensions $\mathrm{SWT}_{\mathrm{i}}$ for each of the $n$ layers in the root zone were weighted according to the ratio of their layer thickness $\left(m_{i}\right)$ to the root depth ( $\left.m_{\text {rootzone }}\right)$ and summed up. The aim of this index was to identify intervals with intense water deficit in the soil, assuming that in these time periods plants had to overcome high soil water tension in order to access water.

$\mathrm{SWT}_{\text {rootzone }}=\sum_{i=1}^{n} \mathrm{SWT}_{\mathrm{i}} \cdot \frac{m_{i}}{m_{\text {rootzone }}}$ 


\subsubsection{Evapotranspiration difference $\left(\mathbf{E} \mathbf{T}_{\text {Diff }}\right)$}

ET $_{\text {Diff }}$ was calculated after Eq. (2) for each time step. The main purpose of $\mathrm{ET}_{\text {Diff }}$ was to find time steps in which, due to intense radiation, a high evapotranspiration $\left(\mathrm{ET}_{\mathrm{pot}}\right)$ was possible but only small values for evapotranspiration $\left(\mathrm{ET}_{\text {real }}\right)$ were realized because of a low soil water content

$\mathrm{ET}_{\text {Diff }}=\mathrm{ET}_{\text {pot }}-\mathrm{ET}_{\text {real }}$.

\subsubsection{Soil water content (SWC)}

For the calculation of this index, as shown in Eq. (3), the soil water content in the root zone $\mathrm{SWC}_{\text {rootzone }}$ was required. The difference between actual relative soil water content $\left(\mathrm{SWC}_{i}\right)$ and the relative soil water content representing the permanent wilting point $\left(\mathrm{PWP}_{i}\right)$ was calculated for each of the $n$ layers in the rootzone. In order to obtain an absolute value in millimetres, the difference representing the actual water content available to plants, was multiplied by the thickness of the corresponding layer $m_{i}$. The index aimed at locating critical water conditions for plants. Thus, the index was able to indicate time steps with insufficient soil water content

$\mathrm{SWC}_{\text {rootzone }}=\sum_{i=1}^{n}\left(\mathrm{SWC}_{i}-\mathrm{PWP}_{i}\right) \cdot m_{i}$

\subsubsection{Processing of drought stress indices}

In order to obtain annual index values, the daily values of the indices were compared to specific conditions and counted per growing period. To this end, it was checked whether a day belonged to the growing period of the considered year. This was true if the mean temperature of a specific day and its four previous days equalled or exceeded $10^{\circ} \mathrm{C}$. The results for each growing period were set in relation to 100 days in order to achieve the percentage of the vegetation period characterised by drought stress and to compare single years.

In the analysis of the index SWT the mean soil water tension in the root zone $\mathrm{SWT}_{\text {rootzone }}$ was compared to a threshold soil water tension. This was done for three physically based thresholds, a soil water tension of 3.5, 3.8 and 4.0, respectively. The thresholds for the index $\mathrm{ET}_{\text {Diff }}$ were chosen to be 4,6 and $8 \mathrm{~mm}$. These values are not physically based, but experimentally determined by analysing the index results. For both indices the thresholds were intended to represent values at which stress situations for the plants started. In contrast to the two abovementioned indices, for SWC a daily weighting factor depending on $\mathrm{SWC}_{\text {rootzone in millime- }}$ tres was determined. $\mathrm{SWC}_{\text {rootzone }}$ was compared to soil specific thresholds. The relevant thresholds were defined at half of the available water capacity $(\mathrm{AWC} / 2)$, a quarter of the available water capacity (AWC/4) and the permanent wilting point (PWP). To each of these values an amount of nine
Table 1. Weighting factors for drought stress index SWC depending on $\mathrm{SWC}_{\text {rootzone. }}$

\begin{tabular}{ll}
\hline $\begin{array}{l}\text { weighting } \\
\text { factor }\end{array}$ & condition \\
\hline 1 & $\mathrm{SWC}_{\text {rootzone }}<\mathrm{PWP}+9 \mathrm{~mm}$ \\
0.7 & $\mathrm{AWC} / 4+9 \mathrm{~mm}>\mathrm{SWC}$ rootzone $\geq \mathrm{PWP}+9 \mathrm{~mm}$ \\
0.5 & $\mathrm{AWC} / 2+9 \mathrm{~mm}>\mathrm{SWC}$ rootzone $\geq \mathrm{AWC} / 4+9 \mathrm{~mm}$ \\
0 & $\mathrm{SWC}_{\text {rootzone } \geq \mathrm{AWC} / 2+9 \mathrm{~mm}}$ \\
\hline
\end{tabular}

millimetres was added, which estimated 3 times the average daily water need of $3 \mathrm{~mm}$ as rough value for forest stands (AStOK, 2003). Table 1 shows the different weighting factors and their corresponding conditions for SWC.

\section{Results}

\subsection{Model behaviour}

Using the derived parameters the model was sensitive to changes in available water capacity, slope angle and exposition (Fig. 1) e.g. such that a site with a high AWC dried out less intensely in case of aridity than a site with low AWC. For a south-exposed site again the soil water deficit grew higher than for a north-exposed site of the same slope. The degree of this drying up was clearly depending on the parameterisation of the site. The mentioned differences between the sites were distinctive in dry and warm years. However in colder and humid years such behaviour was not visible.

\subsection{Results of drought stress indices}

In the following section the index results of the even site simulation for an available water capacity of $150 \mathrm{~mm}$ are shown exemplarily in order to determine the behaviour and suitability of the indices.

\subsubsection{Using measured climate data}

The index SWT yielded the maximum percentage of drought stress in the vegetation period for all three thresholds in 1976, an extremely warm and dry year. For the thresholds of 3.5 and 3.8 the years 1952, 1964, 1973 and 1976 showed intense drought stress. The years 1959 and 1989 were also indicated with the threshold of 4.0 (Fig. 2). Figure 3 shows that the chosen thresholds for $\mathrm{ET}_{\text {Diff }}$ of four, six and eight millimetres were exceeded in every growing period from 1951 to 2003. Furthermore, the value range of the percentage of drought stress in the vegetation period was considerably low, but differences between single years can be seen. Hot and dry years like 1959, 1973, 1976 and 2003 were indicated and also wet and cool years such as 1965, 1968 or 1987 were recognized. The index SWC yielded sufficient soil water content during 

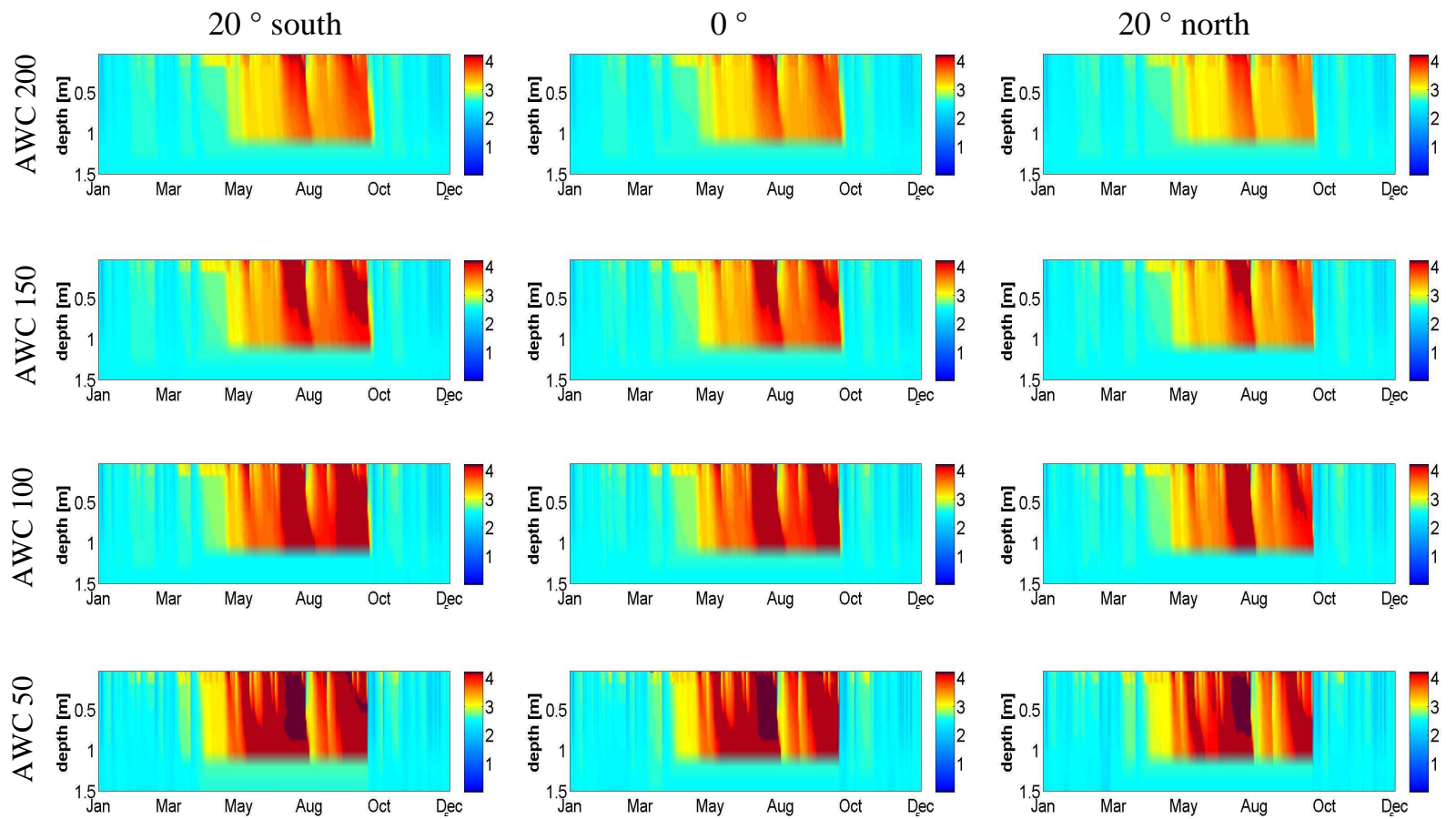

Fig. 1. Simulated soil water tension in $\mathrm{pF}$ up to $1.5 \mathrm{~m}$ depth for all site variations and the year 1982; with climate data of the station "Deuselbach", Germany.

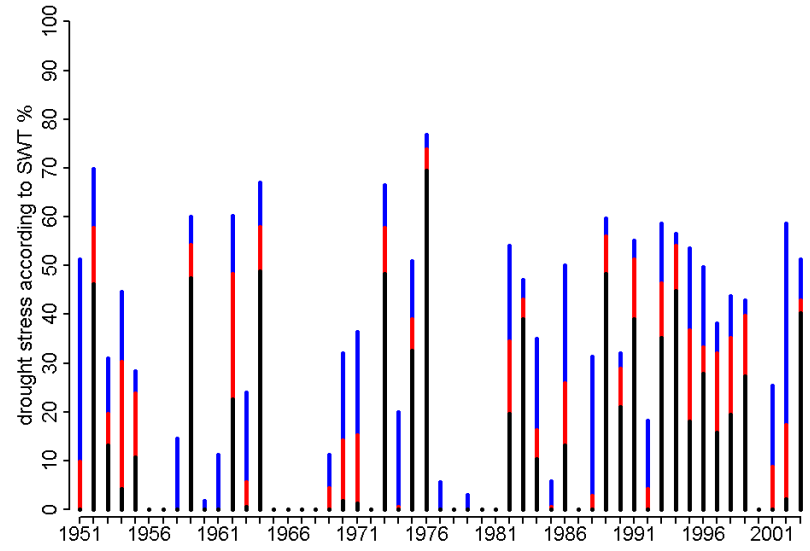

Fig. 2. Drought stress index SWT with thresholds of $\mathrm{pF}=3.5$ (blue), $\mathrm{pF}=3.8$ (red) and $\mathrm{pF}=4$ (black) for an even site and an available water capacity of $150 \mathrm{~mm}$; period 1951-2003; climate station "Deuselbach", Germany.

the vegetation period for several years, such as 1956 or 1987. For other years such as 1952, 1964, 1973 or 1976 however, SWC indicated a high percentage of the vegetation period with drought stress. Especially for the year 1976 an intense drought stress period was indicated (Fig. 4).

The comparison of the two indices SWC (Fig. 4) and SWT (Fig. 2) showed that periods of drought stress were indicated for mostly the same years. Furthermore, the relative assessments for individual years were quite similar for the two indices SWC and SWT, although the values for SWC were

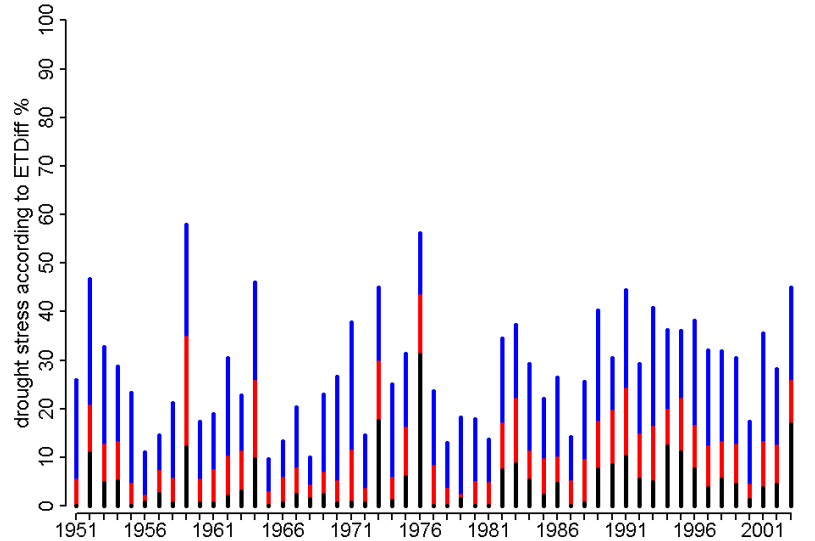

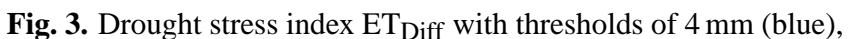
$6 \mathrm{~mm}$ (red) and $8 \mathrm{~mm}$ (black) for an even site and an available water capacity of $150 \mathrm{~mm}$; period 1951-2003; climate station "Deuselbach", Germany.

mostly higher than those of SWT. For a number of years some differences can be seen, for example in 1971 or 2002. The similarity of those two indices has to be attributed to the fact that both indices were dependent on the soil water content. Due to the fact that many years were affected by only small percentage of the vegetation period with drought stress whereas others such as 1976 were indicated with intense drought stress, it can be concluded that both indices, SWT and SWC, were selective indices. In contrast $\mathrm{ET}_{\text {Diff }}$ (Fig. 3) did not show large differences between single years. Thus $\mathrm{ET}_{\text {Diff }}$ was not such a selective index. 


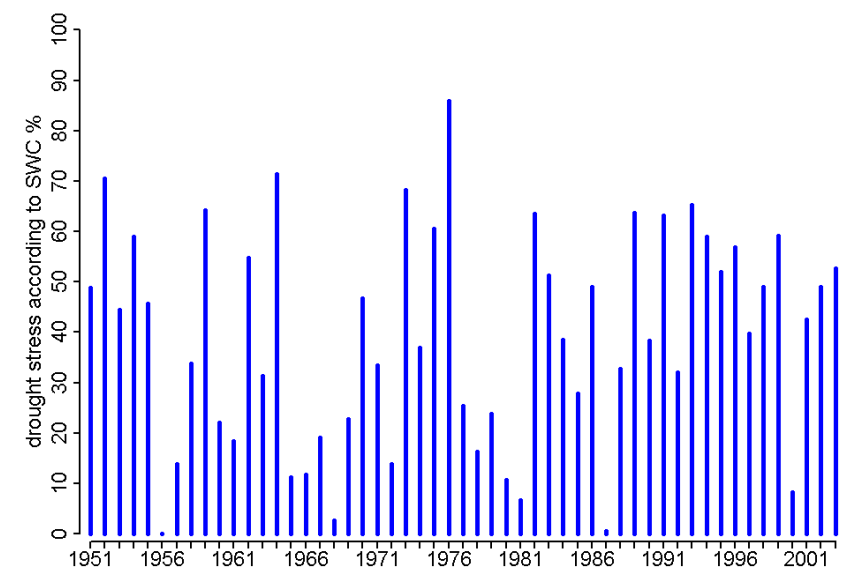

Fig. 4. Drought stress index SWC for an even site and an available water capacity of $150 \mathrm{~mm}$; period 1951-2003; climate station "Deuselbach", Germany.

If one of the two water balance based indices, for example SWT, was compared to $\mathrm{ET}_{\text {Diff, }}$ an index that depends on the evapotranspiration, the results were different. ET $_{\text {Diff }}$ indicated every year with at least a certain percentage of drought period, whereas the year 1976 was only ranked second and did not catch the eye as clearly as for the indices SWT or SWC. Furthermore, it can be seen that SWT and ET $_{\text {Diff }}$ stressed the year 2002 in a different way. The index SWT ranked it as number eight in years with drought stress whereas the index $\mathrm{ET}_{\text {Diff }}$ positioned it as number 26.

\subsubsection{Using projections of future climate}

The comparison between measured climate data (19512003) and the future scenario A1B normal from 2061 to 2100 showed an increase in the frequency of drought periods (mean value of the percentage of vegetation period with drought stress) for all three observed indices (Table 2). The increase in the mean value of the indices was most significant for SWT with a factor of 1.9. But also for SWC and ET Diff $_{\text {f }}$ with factors of 1.6 respectively 1.5 a significant increase was observed. The standard deviation showed decreases for all three of the presented indices.

For index SWC the comparison between measured climate data and future scenario showed more frequent drought periods (Fig. 5). For the measured climate data the majority of years showed a uniform distribution of the percentage of drought stress from zero up to $70 \%$. The results of the climate scenarios however showed a significant shift towards higher percentage and were dominated by values between 50 and $80 \%$. The drought stress index $\mathrm{ET}_{\text {Diff }}$ showed for both time periods a comparable distribution but for the future scenario a shift towards higher frequencies of drought periods became clearly visible (Fig. 6).
Table 2. Statistical values of drought stress in $\%$ according to the indices SWT (3.5), SWC and $\mathrm{ET}_{\text {Diff }}(4 \mathrm{~mm})$ for an even site with an AWC of $150 \mathrm{~mm}$, for measured and projected climate data (WETTREG, A1B normal) of the station "Deuselbach", Germany.

\begin{tabular}{lcccr}
\hline & \multicolumn{2}{c}{ measured } & \multicolumn{2}{c}{ projection } \\
& $(1951-2003)$ & \multicolumn{2}{c}{$(2061-2100)$} \\
& mean & $\mathrm{s}^{2}$ & mean & $\mathrm{s}^{2}$ \\
\hline SWT (3.5) & 30.82 & 24.46 & 59.18 & 15.56 \\
SWC & 38.84 & 21.48 & 63.24 & 13.76 \\
ET $_{\text {Diff }}(4 \mathrm{~mm})$ & 28.35 & 11.64 & 43.27 & 9.12 \\
\hline
\end{tabular}
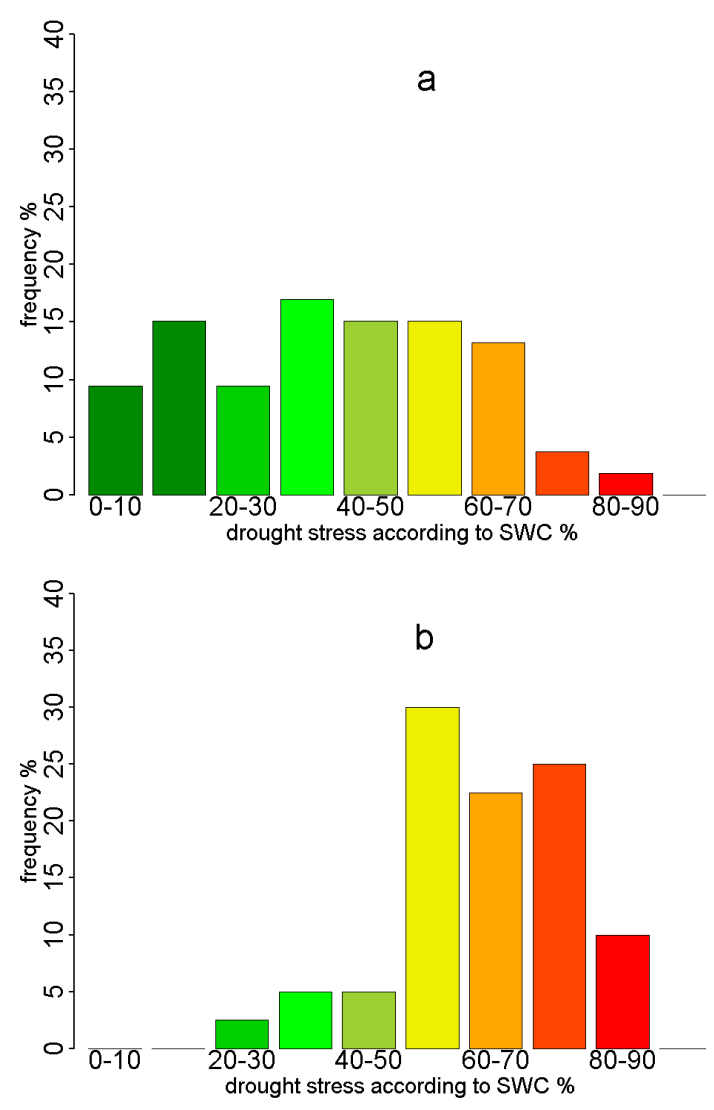

Fig. 5. Histogram of drought stress index SWC for (a): simulations with measured climate data (1951-2003) and (b): simulations with climate projections (2061-2100, WETTREG A1B normal); even site and an available water capacity of $150 \mathrm{~mm}$; climate station "Deuselbach", Germany.

\section{Discussion and outlook}

Similar to concepts applied in other states of Germany, the aim of this concept is to link climate, terrain and soil parameters with biomass productivity. In order to reach this aim plausible hydrological simulations for different water balance conditions are needed. The different water balance 

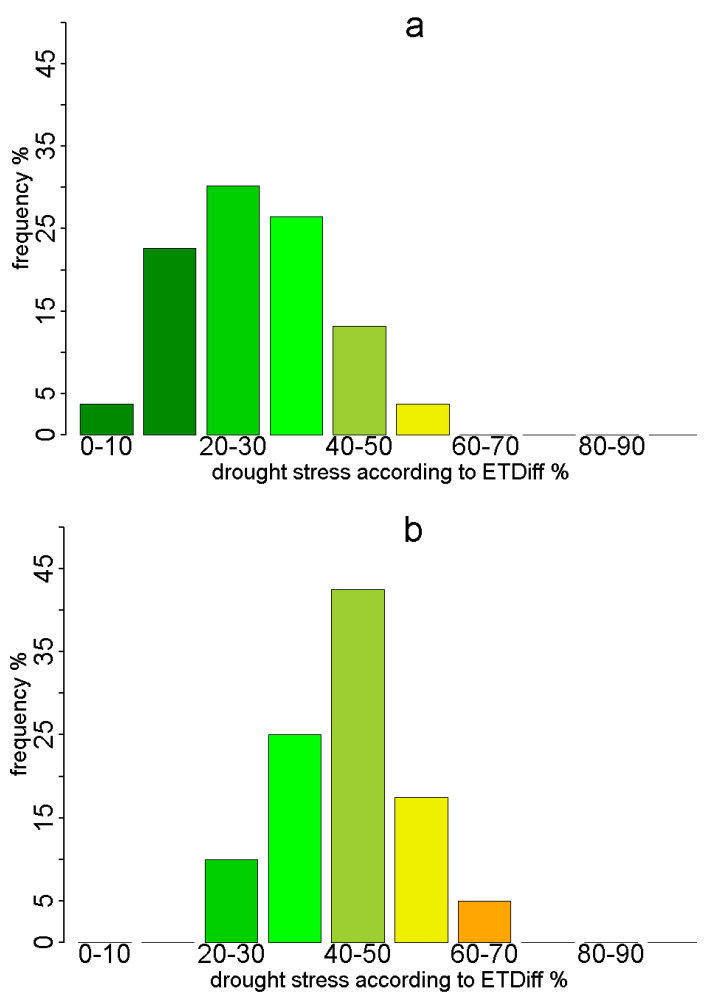

Fig. 6. Histogram of drought stress index $\mathrm{ET}_{\text {Diff }}($ threshold $=4 \mathrm{~mm}$ ) for (a): simulations with measured climate data (1951-2003) and (b): simulations with climate projections (2061-2100, WETTREG A1B normal); even site and an available water capacity of $150 \mathrm{~mm}$; climate station "Deuselbach", Germany.

conditions are represented by changing available water capacity, comparable to Falk et al. (2008) and topology. Analogous to Schwärzel et al. (2008) especially sites with low available water capacities and south exposed sites show a significant higher liability to dehydration. In the next step several drought stress indices are applied to those simulations. For $\mathrm{ET}_{\text {Diff }}$ there are two main differences concerning the resembling transpiration difference index ( $\left.T_{\text {Diff }}\right)$ used in Bavaria (Falk et al., 2008; Schultze et al., 2005): on the one hand, in contrary to $T_{\text {Diff }}, \mathrm{ET}_{\text {Diff }}$ additionally includes the evaporation and on the other hand not a sum of the deficit is calculated but by means of a threshold a number of extreme days is counted. For SWC in contrary to Schwärzel et al. (2008) not one condition is set but four, which improve the sensitivity of the index.

SWT, ET $T_{\text {Diff }}$ and SWC do not always indicate the same years as critical. The different results are clearly depending on the values used for water balance and the chosen thresholds. Furthermore, between the indices differences in sensitivity could be observed. Furthermore, the application of

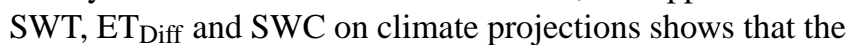
drought stress indices are able to detect the impact of climate change on water balance and are consequently capable for the following analysis.
Future work will be directed towards testing further stress indices and combine different indices in order to find the most appropriate one, which corresponds best to the field experience of biomass productivity. In addition, the results of the indices will be compared to biomass productivity data of long-time monitored forest sites. Similar to the concept of Schwärzel et al. (2008) the link between these two variables will be developed. Finally a correlation between climate parameters and drought stress indices (compare Schultze et al., 2005) will be analysed to find appropriate climate parameters to determinate the water regime as important part of forest site mapping. Further simulations with varying soil texture will be carried out, in order to represent the behaviour of different soil characteristics in Rhineland-Palatinate.

Acknowledgements. This study was supported by the ministry of environment of Rhineland-Palatinate, Germany, which advances the interdisciplinary research project dealing with "climate and land use change in Rhineland-Palatinate" (KlimLandRP, www.klimlandrp.de). The authors thank both reviewers and the editor.

Edited by: A. Wahren, F. Tavares Wahren, and K.-H. Feger

Reviewed by: two anonymous referees

\section{References}

AG Boden (Ad-Hoc-Arbeitsgruppe Boden der Staatlichen Geologischen Dienste und der Bundesanstalt für Geowissenschaften und Rohstoffe): Bodenkundliche Kartieranleitung, 5. Auflage, Schweizerbart, Stuttgart, 2005 (in German).

AStOK (Arbeitskreis Standortskartierung in der Arbeitsgemeinschaft Forsteinrichtung): Forstliche Standortsaufnahme, IHW, Eching, 6. Aufl., 352 pp., 2003 (in German).

Asche, N.: Forstliche Standortklassifikation mit digitalen Werkzeugen - Eine Fallstudie im Kartiergebiet Bad Driburg, LÖBF Recklinghausen, 11 pp., available at: http://www.wald-und-holz.nrw. de/50Wald_und_INFO/Forstliche_Veroeffentlichungen/2000/ Forstl_Standortklassifikation_digital_Dr_Asche_2000.pdf (last access: 6 May 2010), 2001 (in German).

Ellenberg, H., Mayer, R., and Schauermann, J.: Ökosystemforschung - Ergebnisse des Sollingprojekts, Verlag Eugen Ulmer, Stuttgart, 1986 (in German).

Engesser, R., Forster, B., Meier, F., and Wermelinger, B: Forstliche Schadorganismen im Zeichen des Klimawandels, Schweiz Z. Forstwes., Pfäffikon, 159(10), 344-351, 2008 (in German).

Falk, W., Dietz, E, Grünert, S., Schultze, B., and Kölling, C.: Wo hat die Fichte genügend Wasser?, available at: http://www.lwf.bayern.de/veroeffentlichungen/lwf-aktuell/66/ a66_06_falk_dietz_gruenert_schultze_koelling.pdf (last access: 20 November 2009), 2008 (in German).

Gauer, J.: Böden als Waldstandorte, in: Handbuch der Bodenkunde, 32. Erg.Lfg 06/09, 4.2.1, Blume, H.-P., Felix-Henningsen, P., Fischer, W. R., u.a. (Hrsg), Wiley-VCH, Weinheim, 79 pp., 2009 (in German).

Laatsch, W.: Das Abschätzen der Wasserversorgung von Waldbeständen auf durchlässigen Standorten ohne Grundund Hangzugwasser - 1. Teil. Leicht durchlässige Standorte, 
Forstwiss. Cent.bl., 88JG, 257-271, Hamburg, 1969 (in German).

Monteith, J. L. and Unsworth, M. H.: Principles of Environmental Physics,2nd edn., Edward Arnold, London, UK, 1990.

Oke, T. R.: Boundary Layer Climates, 2nd edn., Routledge, London and New York, 435 pp. 1987.

Petercord, R.: Zukünftige Gefährdung der Rotbuche durch rindenund holzbrütende Käfer in Baden-Württemberg, Mitt. Dtsch. Ges. allg. angew. Ent., Giessen, 16, 247-250, 2008 (in German).

Sauer, T.: Modellierung von Bodenwasserhaushalt und Abflussprozessen auf der Plotskale in Abhängigkeit von Substrat und Landnutzung, Dissertation, Universität Trier, Germany, 2009 (in German).

Schulla, J. and Jasper, K.: Model description WaSiM-ETH, Zürich, available at: http://www.wasim.ch/downloads/doku/ wasim/wasim_2007_en.pdf (last access: 27 November 2008), 2007.

Schultze, B., Kölling, C., and Dittmar, C. R.: Konzept für ein neues quantitatives Verfahren zur Kennzeichnung des Wasserhaushalts von Waldböden in Bayern, Forstarchiv 76. Jahrgang, 155-163, 2005 (in German).

Schwärzel, K., Häntzschel, J., Menzer, A., Spank, U., Clausnitzer, F., Köstner, B., Bernhofer, C., and Feger, K.-H.: Modellierung und Regionalisierung des Standortwasserhaushaltes von Wäldern im Mittelgebirge, available at: http://www.afsv.de/download/arbeitsgruppe/ Schwaerzel_Text_Freiburg_7Juli2008.pdf (last access: 27 October 2009), 2008 (in German).
Spekat, A., Enke, W., and Kreienkamp, F.: Neuentwicklung von regional hoch aufgelösten Wetterlagen für Deutschland und Bereitstellung regionaler Klimaszenarios auf der Basis von globalen Klimasimulationen mit dem Regionalisierungsmodell WETTREG auf der Basis von globalen Klimasimulationen mit ECHAM5/MPI-OM T63L31 2010 bis 2100 für die SRESSzenarios B1, A1B und A2, 94 pp., available at: http://www.umweltdaten.de/publikationen/fpdf-1/3133.pdf (last access: 19 May 2008), 2006 (in German).

Teepe, R., Dilling, H., and Beese, F.: Estimating water retention curves of forest soils from texture and bulk density, J. Plant Nutr. Soil Sci,, 166, 111-119, 2003.

van Genuchten, M. T.: A closed-form equation for predicting the hydraulic conductivity of unsaturated soils, Soil Sci. Soc. Am. J., 44, 892-898, 1980.

Wessolek, G.: Einsatz von Wasserhaushaltsmodellen und Photosynthesemodellen in der Ökosystemanalyse, in: Landschaftsentwicklung und Umweltforschung, Schriftenreihe des Fachbereiches Landschaftsentwicklung der TU Berlin, 170 pp., Berlin, 1989 (in German). 